\title{
4.12 Інноваційні аспекти освітньої мобільності у системі післядипломної освіти
}

На сучасному етапі розвитку та уніфікації освітніх систем, глобалізації та активізації міжнародної діяльності, швидкого застарівання знань, переходу від концепції «освіти на все життя» до концепції «освіти впродовж життя» мобільність стає однією із ключових характеристик сучасної освіти і науки. Освітня мобільність є невід'ємним компонентом дискурсу щодо питань глобалізації освіти, найбільш розвиненою формою ii iнтернаціоналізації, забезпечує доступ по провідних наукових здобутків розвинених країн, підтримує розвиток міжкультурної взаємодії, є принциповою характеристикою єдиного освітнього простору. За твердженням М. Култаєвої, навчання протягом усього життя - це відкрита освіта, яка принципово не може бути завершеною. Структура безперервної освіти $є$ гнучкою, включає в себе альтернативні можливості і форми. Вона є просторово і інституційно відкритою і відповідає вимогам активного і мобільного суспільства [378].

Сьогодні явище мобільності пов'язують 3 багатьма науками, зокрема, філософією, соціологією, педагогікою, психологією, демографією, географією, економікою, державним управлінням, правом, політологією, історією. У довідникових джерелах мобільність розглядається як «рухливість, здатність швидко орієнтуватися в ситуації, знаходити потрібні форми діяльності» [379]. У працях сучасних науковців найчастіше зустрічаються такі трактування поняття «мобільність»:

- міра здатності фактора виробництва до переміщення між сферами використання [380];

- рухливість, готовність до швидкої реакції, швидкого включення в діяльність [381];

- одна із сутнісних характеристик людини, яка проявляється в процесі праці, тобто професійній діяльності. Мобільний фахівець повинен являти собою людину як універсум [382]; 
- як специфічний освітній феномен, асоційований із процесами забезпечення взаємодії національних освітніх просторів, з іншого - як метафора соціального розвитку [383].

Мобільність науковці також розглядають не лише як рух суб’єкта чи предмета, але й процеси, причини, результати, вона стає атрибутом людей, ідей, інформації, цінностей тощо.

Слід зазначити, що зміна парадигми освіти викликала інтерес науковців і педагогів-практиків до «підвищення кваліфікації викладачів, що зумовлений переходом від масово-репродуктивних форм i методів викладання до індивідуально-творчих, коли готується фахівець зі сформованою потребою в професійній самоосвіті, здатний до саморозвитку і повноцінної самореалізації в обраній професії» [384].

А професійна мобільність, за визначенням дослідниці Л. Сушенцевої, це якість особистості, що є необхідною для успішної життєдіяльності в сучасному суспільстві, яка забезпечує ії самовизначення, самореалізацію і саморозвиток у праці, завдяки сформованим ключовим компетенціям та ключовим кваліфікаціям і прагненню особистості змінити не тільки себе, а й професійне поле та життєве середовище [385]. Вперше поняття «професійна мобільність учителів шкіл» використано у 1913 році у звіті бюро освіти США, розглядалося «у професії [вчителя] дуже бажана як розумна мобільність, так й розумна стабільність [386].

На нашу думку, професійна мобільність є якісною складовою особистості як фахівця; іï формування має розпочинатися ще під час навчання в закладі вищої освіти. У Свропі поняття «професійна мобільність» розглядається через фундаменталізацію освіти. Французький учений Ф. Ваніскотт обгрунтував концепцію мобільності вчителя-європейця, яка розглядається як здатність до змін, до прийняття нового.

Тому феномен освітньої мобільності ми трактуємо як один із засобів організації освіти нового типу, яка б гармоніювала із сучасними соціальними 
запитами та відповідала б вимогам щодо флексибільного характеру своєї сутності.

Під професійною мобільністю ми розуміємо прагнення людини досягти визнання, самореалізації та творчості шляхом здійснення професійної діяльності, яка приносить моральне та психологічне задоволення паралельно із високим матеріальним доходом, а також готовність до зміни професійної діяльності та здобуття нової освіти у зв'язку із попитом на них соціального кола рівня особистості або за власним бажанням.

У рамках неперервної професійної освіти розглянемо особливості організації діяльності закладів післядипломної педагогічної освіти та розвиток професійної мобільності педагогів. У контексті нашого дослідження важливого значення набуває галузева Концепція розвитку неперервної педагогічної освіти, яка $є$ стратегічним документом, що визначає основні напрями розвитку педагогічної освіти в Україні [387]. Основними принципами розвитку неперервної педагогічної освіти в цьому документі визначено: неперервність, поєднання національних освітніх традицій та найкращого світового досвіду, інноваційність, прогностичність, гнучкість у реагуванні на суспільні зміни.

Під розвитком професійної мобільності педагога науковці розуміють процес набуття нових та удосконалення існуючих компетенцій, знань, умінь та навичок, які він використовує або буде використовувати в своїй професійній діяльності. Становлення й розвиток професійної мобільності педагога забезпечується особистісним творчим перетворенням освітньої й професійно-педагогічної дійсності.

В умовах системи неперервної професійної освіти розвиток професійної мобільності вчителя відбувається за рахунок залучення потенціалу системи додаткової професійної освіти, використання досвіду закордонних систем освіти, а також з урахуванням особистісних якостей і потреб педагога.

Відкрите суспільство зацікавлене у фахівцях, які самостійно думають, творчо вирішують різноманітні завдання, володіють критичним мисленням, здатні до самонавчання і самоосвіти. Тому сучасні умови професійної 
діяльності у сфері освіти вимагають від педагога мобільності, оволодіння такими якостями, як педагогічна реакція, цілеспрямованість, передбачення, прогнозування 3 метою досягнення цілей і попередження виникнення ризиків. Система післядипломної освіти може забезпечити розвиток професійної мобільності педагога, якщо буде: створювати умови для всебічного гармонійного розвитку, незалежно від віку, попередньо здобутої професії або спеціальності, місця проживання, але 3 обов'язковим урахуванням іiі індивідуальних особливостей, мотивів, інтересів; запроваджувати форми, методи і технології розвитку професійної мобільності педагога для здобуття та вдосконалення професійно педагогічних знань високого рівня, узагальнення та уміннями їх ефективно застосовувати; сприяти попередженням професійної деформації, вибудові та реалізації напряму свого подальшого професійного зростання.

Сучасна система післядипломної освіти має великі можливості для забезпечення розвитку професійної мобільності педагога, адекватного реагування на зміни в сфері освіти, впровадження технологій, які забезпечуватимуть професійне вдосконалення, підвищення кваліфікації педагогічних працівників згідно з вимогами інноваційного розвитку освіти та забезпечення випереджувального характеру підвищення кваліфікації відповідно до потреб реформування системи освіти.

Професійний розвиток тісно пов'язаний з особистісним. Особистісні якості у процесі професійної діяльності забезпечують спрямованість особистості на самовдосконалення. Розвиток професійної мобільності педагога $є$ засобом активізації професійних якостей фахівця, актуалізації його внутрішніх резервів і можливостей, формування здатності самореалізації у професійній діяльності.

Ми вважаємо, що розвиток професійної мобільності - це безперервний процес оновлення знань та вдосконалення професійних компетенцій, який зумовлений ускладненням та мобільністю сучасного суспільного життя, розширенням сфер діяльності людини, обмеженням набутих компетентностей, 
що, в свою чергу, зумовили необхідність розвитку професійної мобільності педагогів у системі післядипломної освіти.

В Україні післядипломну освіту офіційно визначено як «спеціалізоване вдосконалення освіти та професійної підготовки особи шляхом поглиблення, розширення та оновлення їі професійних знань, умінь та навичок або отримання іншої професії, спеціальності на основі здобутого раніше освітнього рівня та практичного досвіду» [388]. Стаття 59 Закону України «Про освіту» для професійного розвитку педагогічних $\mathrm{i}$ науково-педагогічних працівників передбачає постійну самоосвіту, участь у програмах підвищення кваліфікації та будь-які інші види і форми професійного зростання. Заклади освіти, в яких працюють педагогічні та науково-педагогічні працівники, сприяють їхньому професійному розвитку та підвищенню кваліфікації [389].

Післядипломну освіту здійснюють заклади післядипломної освіти або відповідні структурні підрозділи вищих навчальних закладів і наукових установ [389]. Заклади післядипломної педагогічної освіти - це вищі навчальні заклади, що здійснюють підвищення кваліфікації та перепідготовку педагогічних кадрів на основі здобутого раніше освітньо-кваліфікаційного рівня, практичного досвіду відповідно до замовлень управлінь освіти і науки обласної державної адміністрації, закладів освіти, юридичних та фізичних осіб. Як зазначають науковці, завданням післядипломної освіти $\epsilon$ розвиток та вдосконалення особистісних якостей фахівця та створення умов для самореалізації, самоактуалізації педагога, вдосконалення самоосвітньої діяльності, виходячи 3 цього основними функціями післядипломної освіти є: підвищення кваліфікації, підготовка та перепідготовка фахівців відповідно до потреб ринку праці у фахівцях певного профілю; постійне оновлення знань, умінь та навичок згідно 3 вимогами суспільства, ринку праці, техніки і технологій; створення умов для професійного та особистісного розвитку фахівця.

Система післядипломної педагогічної освіти забезпечує оптимальні умови для самореалізації особистості, розкриття всіх закладених у ній потенційних ресурсів, здібностей шляхом: 
•переходу від одноразового курсового підвищення кваліфікації до моделі неперервного професійного розвитку в умовах формальної, неформальної та інформальної післядипломної освіти;

•надання сервісних послуг на принципах бенчмаркінгової діяльності, що передбачає створення гнучкого, конкурентного освітнього середовища 3 домінуванням мобільних програм підвищення кваліфікації, перевагою активних i практико зорієнтованих технологій навчання, модернізацію змісту, форм, методів, технологій навчання залежно від суспільних та індивідуальних освітніх потреб замовників, відповідно до темпів застарівання і оновлення інформації, можливостей та особливостей, компетентнісного досвіду фахівців;

•розроблення й упровадження в систему підвищення кваліфікації багатоваріантних, різнорівневих, диверсифікованих за профілем освітньопрофесійних програм, форм освіти дорослих, метатехнології відповідно до соціально-педагогічних запитів і особистісно-професійних потреб фахівців, що забезпечують їм свободу вибору місця, термінів, змісту навчання за індивідуальною освітньою траєкторією впродовж життя;

•забезпечення андрагогічних, аксіологічних, акмесинергетичних, культурологічних, інтегративних, навчально-розвивальних, праксеологічних, інформаційних функцій системи підвищення кваліфікації;

•випереджувального характеру надання освітніх послуг в умовах глобалізації і відкритості інформаційного освітнього простору;

•участі фахівців у різних формах академічної мобільності (навчання за програмами академічної мобільності; мовне стажування; наукове стажування, спільні проекти; викладання; наукове дослідження; підвищення кваліфікації);

•підготовки андрагогів для ефективного науково-методичного супроводу професійного розвитку фахівців упродовж життя тощо;

•акумулювання кращих практик розвитку професійної мобільності педагогічних працівників. 
Із розвитком відкритих освітніх ресурсів учитель нового покоління має широкий вибір побудови самоосвітньої діяльності на основі інформаційнокомунікаційних, цифрових, мережевих технологій, на дистанційних платформах тощо. Все це сприяє підвищенню фахового рівня педагогів та розвитку їх професійної мобільності.

Розширення функцій та відповідно сфер діяльності освіти для дорослих, на наш погляд, $є$ загальносвітовою та загальноєвропейською тенденцією, що створює соціокультурні передумови для інноваційного розвитку даної освітньої галузі.

Результати моніторингового дослідження, проведеного Дніпровською академією неперервної освіти у 2021 році серед педагогічних працівників показують, що 95\% опитаних педагогів підтримують ідею впровадження професійної мобільності, 65\% респондентів назвали мобільність фактором, який здатний стимулювати розвиток творчого потенціалу вчителя. Тобто можемо стверджувати, що запровадження мобільності відбувається не лише у вищій школі, але й у системі неперервної професійної освіти.

Мобільність окреслює сучасні тенденції інноваційного розвитку неперервної освіти, є інструментом формування, вдосконалення фахівців, результатом функціонування системи неперервної освіти, а також впливає на етапи формування поняття професійної компетентності. 